\section{Nauplius}

The Journal OF The Brazilian Crustacean Society

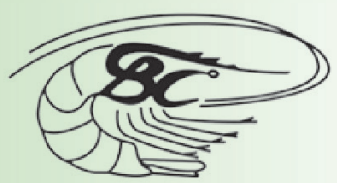

e-ISSN 2358-2936

www.scielo.br/nau www.crustacea.org.br

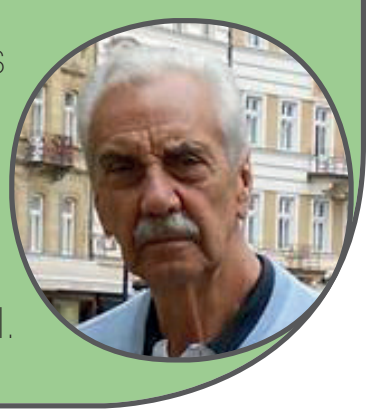

\title{
First zoeal stage of the crab Domecia acanthophora (Desbonne, in Desbonne \& Schramm, 1867) (Decapoda, Brachyura) and revision of the larval morphology of superfamily Trapezioidea
}

Douglas Fernandes Rodrigues Alves ${ }^{1,4}$, João Alberto Farinelli Pantaleão ${ }^{2,4}$, Samara de P. Barros-Alves ${ }^{1,4}$, Rogério Caetano da Costa $^{2,4}$ and Valter José Cobo ${ }^{3,4}$

1 Laboratório de Carcinologia, Universidade Federal de Sergipe, UFS. 49100-000 São Cristóvão, Sergipe, Brazil.

DFRA E-mail: douglas_biologo@yahoo.com.br

SPBA E-mail: barros_samara@hotmail.com

2 Laboratório de Biologia de Camarões Marinhos e de Água Doce - LABCAM, Universidade Estadual Paulista, UNESP. 17033-360 Bauru, São Paulo, Brazil. JAFP E-mail: pantaleaojaf@gmail.com RCC E-mail: rccosta@fc.unesp.br

3 Laboratório de Biologia Marinha - LABBMAR, Universidade de Taubaté, UNITAU. 12030-180 Taubaté, São Paulo, Brazil.

VJC E-mail: vjcobo@gmail.com

4 Group of Studies on Crustacean Biology, Ecology and Culture - NEBECC, Departamento de Zoologia, Universidade Estadual Paulista, UNESP. 18618-970 Botucatu, São Paulo, Brazil.

ZOOBANK http://zoobank.org/urn:lsid:zoobank.org:pub:16FC6416-35D0-41479219-3246E57F55BF

Samara de P. Barros-Alves

barros_samara@hotmail.com

SUBMITTED 24 February 2016 ACCEPTED 13 July 2016

PUBLISHED 21 November 2016

Guest Editors

Maria Lúcia Negreiros-Fransozo and Adilson Fransozo

\section{ABSTRACT}

The morphology of the first zoeal stage of Domecia acanthophora (Desbonne, in Desbonne \& Schramm, 1867) was described from laboratory-hatched material obtained from ovigerous females collected at Vitória Island on the southeastern Brazilian coast. We compared the larval morphology 
(zoea I) of fourteen species of the superfamily Trapezioidea, which Domecia glabra Alcock, 1899 is the only congeneric representative of the species described in this study. The morphological characteristics of the first zoea that distinguish D. acanthophora from D. glabra are: three aesthetascs on the exopod antennule; three pairs of lateral spines on carapace; bilobed basial endite of maxilla, with four plumodenticulate setae on each lobe; and telson furcae distally spinulated. It also provides information that may enhance some phylogenetic hypotheses within Trapezioidea crabs.

\section{KEY WORDS}

Domeciidae, larval description, southeastern Brazil, Tetraliidae, Trapeziidae.

\section{INTRODUCTION}

The most recent Brachyura classification ( $\mathrm{Ng}$ et al., 2008; De Grave et al., 2009; Ahyong et al., 2011) recognizes the superfamily Trapezioidea Miers, 1886, which consists of three families: Domeciidae Ortmann, 1893, Tetraliidae Castro, Ng \& Ahyong, 2004 and Trapeziidae Miers, 1886. Crabs of the family Domeciidae are grouped into four genera: Domecia Eydoux \& Souleyet, 1842, Jonesius Sankarankutty, 1962, Maldivia Borradaile, 1902 and Palmyria Galil \& Takeda, 1986. The species Domecia acanthophora (Desbonne, in Desbonne \& Schramm, 1867) has a wide geographical distribution in the Western Atlantic, extending from North Carolina, Bermuda, Florida, the Gulf of Mexico, the Antilles, northeastern South America and Brazil (St. Peter and St. Paul Archipelago, Rocas Atoll, Fernando de Noronha, and from states of Ceará and Pernambuco to São Paulo) (Alves et al., 2006; Coelho-Filho, 2006; Melo, 1998).

In recent decades, several studies about the morphology of larval stages have been used to elucidate the taxonomic status of these crabs, of which there is still no consensus with respect to the superfamily Trapezioidea (e.g., Clark and Guerao, 2008; Clark and $\mathrm{Ng}, 2010$ ). About 60 species of the superfamily Trapezioidea are known (see Ng et al., 2008), but the morphology of the first zoeal stage is described only for 14 species (see Tab. 1).

Considering the morphology of the first larval stage is unknown for most species of the superfamily Trapezioidea, new descriptions could contribute with knowledge of the relationship within this taxon. Thus, we provided here a detailed description of the first zoea of the crab D. acanthophora, hatched in the laboratory. Additionally, we reviewed and compared the larval morphology (zoea I) of Trapezioidea species (sensu
$\mathrm{Ng}$ et al., 2008) in a comparative table, in order to facilitate the identification of these larvae.

\section{Material AND Methods}

Two ovigerous females of $D$. acanthophora were collected in September 2006 by scuba divers at Vitória Island ( $\left.23^{\circ} 44^{\prime} 04^{\prime \prime} \mathrm{S} 45^{\circ} 01^{\prime} 35^{\prime \prime} \mathrm{W}\right)$ in the southeastern of the São Paulo State, Brazil. The crabs were kept isolated in aquaria filled with seawater from the collecting site, at constant temperature $\left(24 \pm 1^{\circ} \mathrm{C}\right)$, salinity $(35 \pm 1)$ and moderate aeration, until the larvae hatched. Newly hatched zoeae were preserved in a 1:1 mixture of $70 \%$ ethyl alcohol and glycerin. For detailed examination, the larvae and appendages were dissected under a Zeiss Stemi 200C trinocular stereomicroscope and prepared on semi-permanent slides with glycerin.

Drawings and measurements were done using a Leica DM750 microscope equipped with camera lucida. The illustrations and measurements were based on at least 10 specimens. The carapace length (CL) was considered from the eyes (base of the rostrum) to the posterolateral cephalothorax margin, and the rostrodorsal length (RDL) was considered from the tip of the rostral spine to the tip of the dorsal spine. The long terminal plumose natatory setae on distal exopod segments of the first and second maxillipeds were drawn truncated.

Larval description and terminology of setae are based on Clark et al. (1998) and Garm (2004). The parental females of $D$. acanthophora were deposited in the crustacean collection of the Museum of Zoology of the University of São Paulo (MZUSP-16705). The larvae of $D$. acanthophora were deposited in the scientific collection of the Marine Biology Laboratory of the University of Taubaté (UNITAU-201237). 


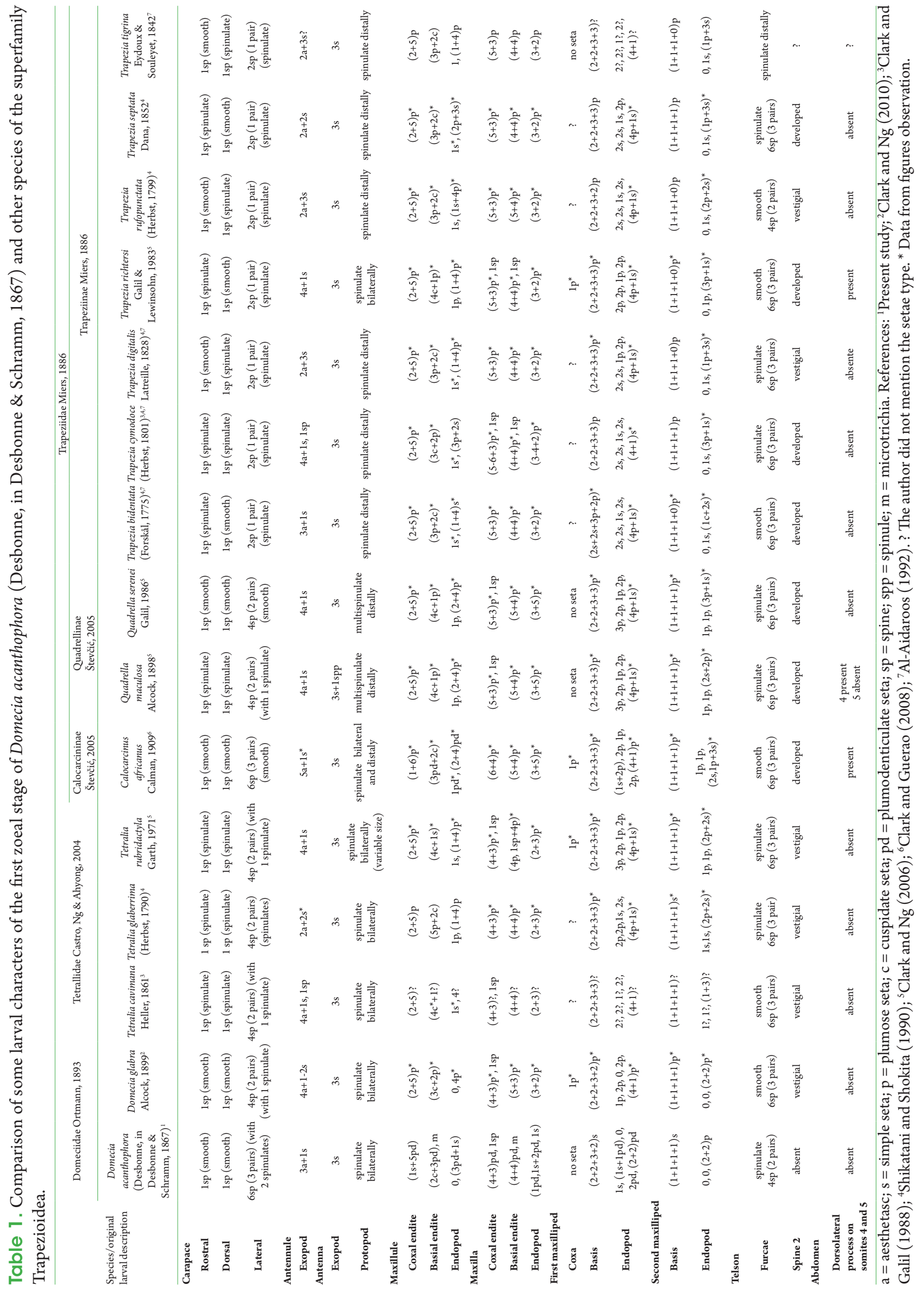




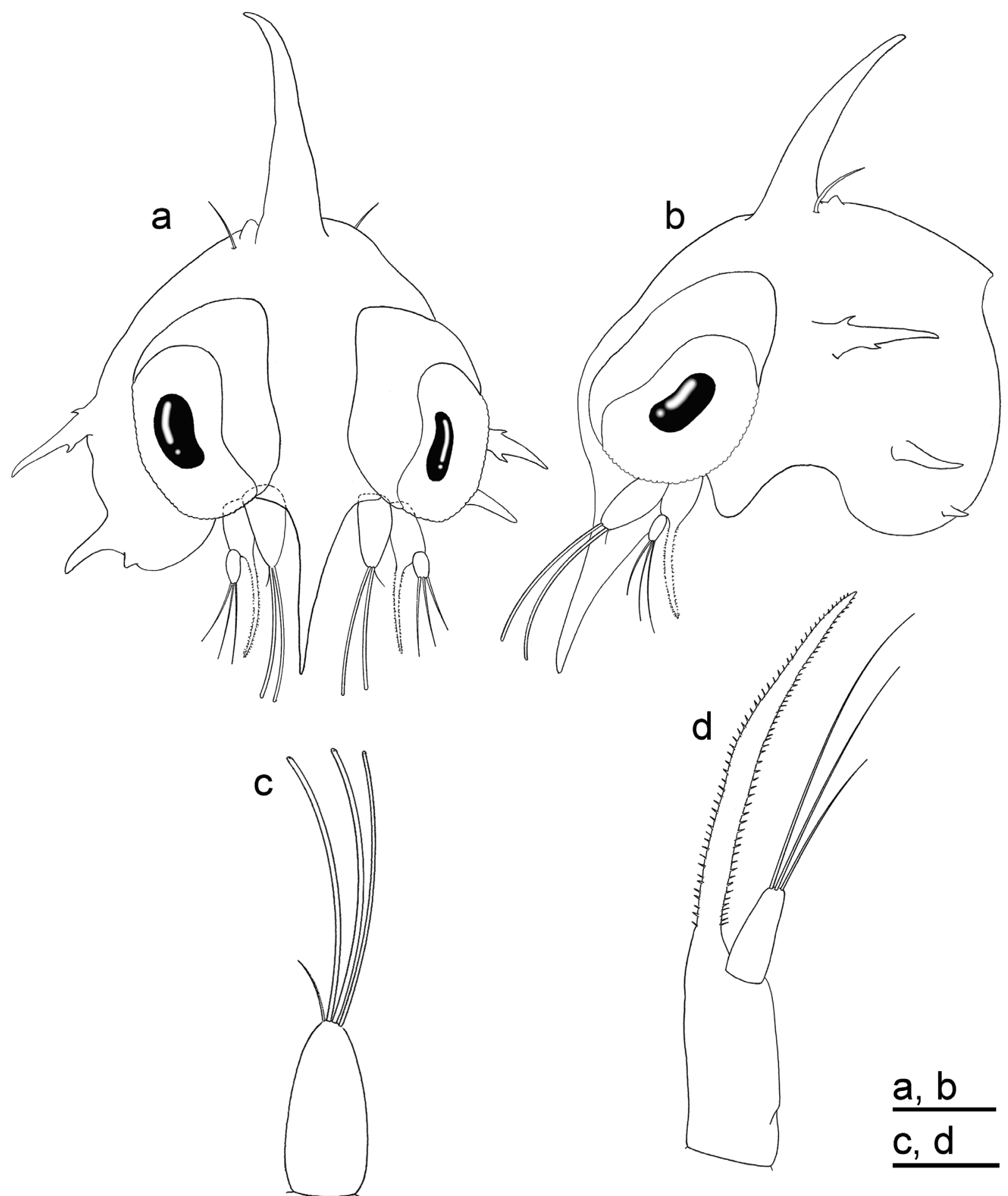

Figure 1. Domecia acanthophora (Desbonne, in Desbonne \& Schramm, 1867), Zoea I. a. Cephalothorax, frontal view; b. Cephalothorax, lateral view; c. Antennule; d. Antenna (scale bars: $a, b=0.1 \mathrm{~mm} ; \mathrm{c}, \mathrm{d}=0.05 \mathrm{~mm}$ ).

\section{Results}

Description of first zoea of D. acanthophora (Figs. 1-3).

Dimensions: CL: $0.38 \pm 0.01 \mathrm{~mm}$; RDL: $0.76 \pm$ $0.02 \mathrm{~mm}(\mathrm{n}=10)$.

Cephalothorax (Fig. 1a, b): dorsal spine smooth, gently curved backward distally, almost equal in length to rostral spine. Pair of posterodorsal simple seta near the basis of the dorsal spine, posterodorsal protuberance present. Three pairs of lateral spines: dorsal pair curved ventrally, with one ventral and one 


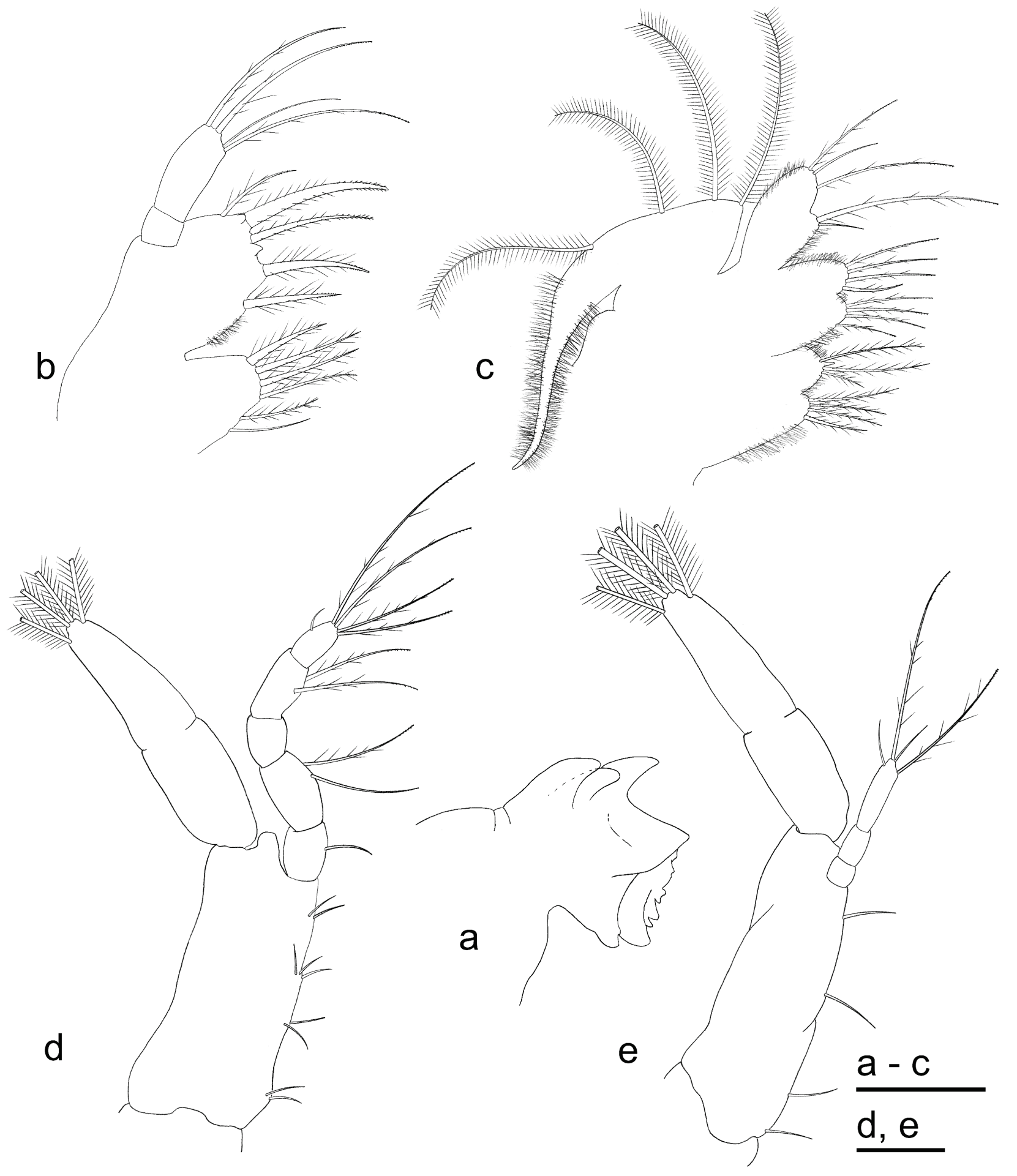

Figure 2. Domecia acanthophora (Desbonne, in Desbonne \& Schramm, 1867), Zoea I. a. Mandible; b. Maxillule; c. Maxilla; d. First maxilliped; e. Second maxilliped (scale bars: a-e $=0.05 \mathrm{~mm}$ ). 


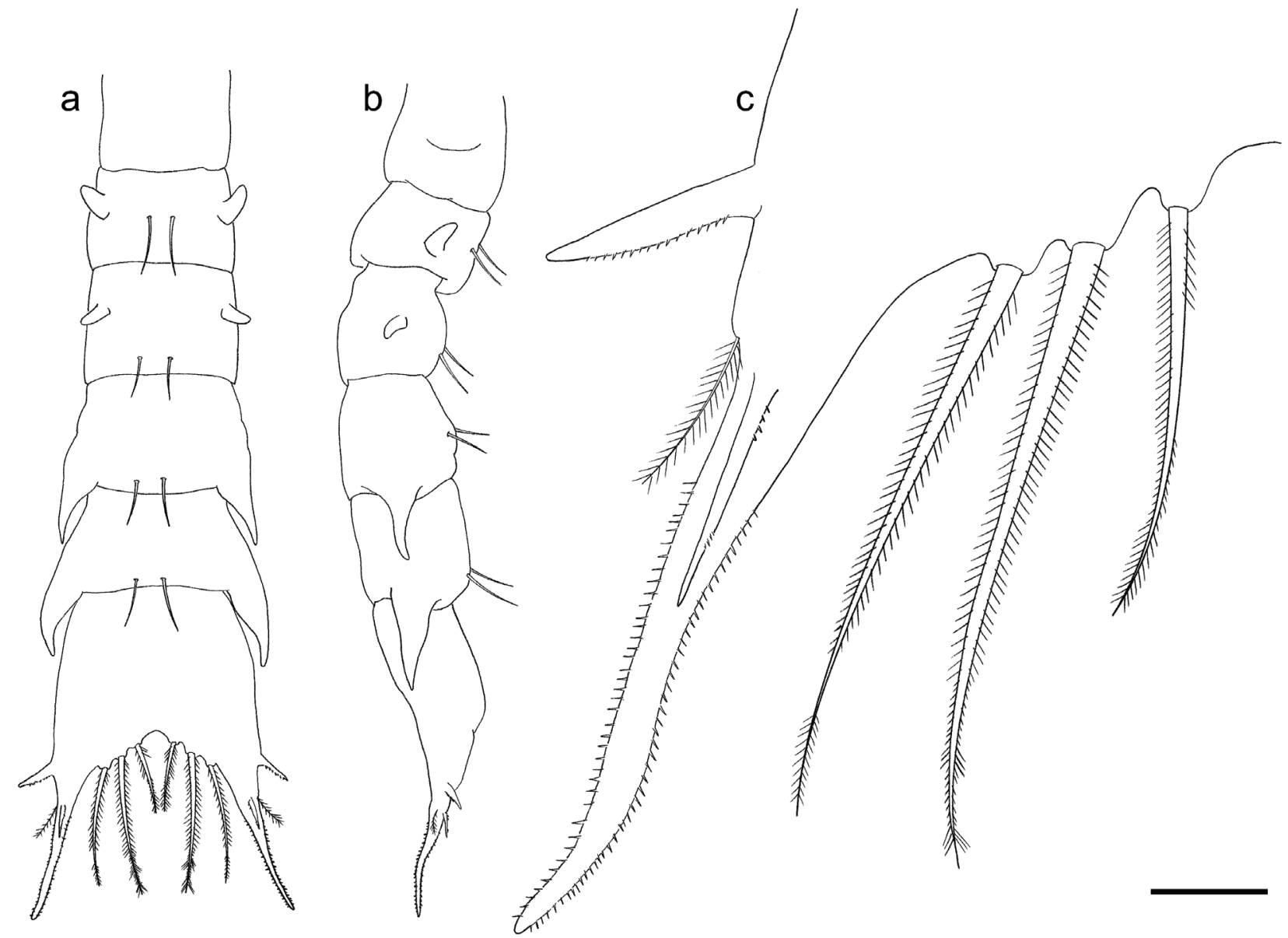

Figure 3. Domecia acanthophora (Desbonne, in Desbonne \& Schramm, 1867), Zoea I. a. Pleon, dorsal view; b. Pleon, lateral view; c. Detail of spinulation of the telson furcae (scale bars: $a, b=0.1 \mathrm{~mm} ; \mathrm{c}=0.02 \mathrm{~mm}$ ).

dorsal spinules; second pair smaller, smooth, slightly curved ventrally; third pair smallest and smooth near carapace margin. Sessile eyes.

Antennule (Fig. 1c): uniramous, smooth. Endopod absent; exopod unsegmented, with three long terminal aesthetascs and one simple seta.

Antenna (Fig. 1d): biramous; well-developed and long protopod, with one row of short, equal spines in each lateral margin of similar sizes. Endopod absent. Exopod unsegmented, with three unequal terminal simple setae, the longest almost equal in length to exopod.

Mandibles (Fig. 2a): incisor and molar processes as illustrated; palp absent.

Maxillule (Fig. 2b): coxal endite with 1 (subterminal) simple and 5 (1 subterminal and 4 terminal) plumodenticulate setae. Basial endite with 5 plumodenticulate setae and 2 small protuberances, microtrichia on proximal margin. Endopod 2 -segmented, proximal segment without seta; distal segment with 3 ( 1 subterminal, 2 terminal) sparsely plumodenticulate setae, 1 shorter subterminal simple seta. Exopod seta absent.

Maxilla (Fig. 2c): coxal endite bilobed, with 4 plumose setae on proximal lobe, 3 plumose setae and 1 terminal small spine on distal lobe. Basial endite bilobed, with 4 plumodenticulate setae on each lobe. Unsegmented endopod bilobed, with 2 (1 plumodenticulate, 1 simple) setae on proximal lobe, 3 ( 1 subterminal, 2 terminal) setae on distal lobe. Exopod (scaphognathite) margin with 4 plumose setae and a long distal process. Microtrichia on both proximal and distal margins of coxal and basial endites, endopod and distal process of the scaphognathite.

First maxilliped (Fig. 2d): coxa without setae. Basis with 9 simple setae arranged $2+2+3+2$. Endopod 5 -segmented with 1 simple seta on first segment; 2 (1 simple, 1 plumodenticulate) setae on second segment; no seta on third segment; 2 plumodenticulate setae on fourth segment; 4 ( 2 subterminal, 2 terminal) 
plumodenticulate setae and one subterminal simple seta on distal segment. Exopod slightly 2-segmented, distal segment with 4 long terminal plumose natatory setae.

Second maxilliped (Fig. 2e): coxa without setae. Basis with 4 simple setae arranged $1+1+1+1$. Endopod 3 -segmented, with 0, 0 and 4 (2 simple, 2 long sparsely plumodenticulate) setae, respectively. Exopod slightly 2 -segmented, distal segment with 4 long terminal plumose natatory setae.

Third maxilliped: absent.

Pereiopods: absent.

Pleon (Fig. 3a, b): five somites. First somite smooth. Second to fifth somites with one pair of posterodorsal simple seta. Second and third somites with one pair of dorsolateral processes. Fourth and fifth somites with long and acute posterolateral processes; pleopods absent.

Telson (Fig. 3a-c): telson furcae distally spinulated and slightly curved outward, with 1 pair of welldeveloped lateral spines (spinulated only on the posterior margin), 1 pair of plumose setae posteriorly to the well-developed spines, and one pair of dorsal spines (spinulated only on the proximal inner margin); inner margin with 3 pairs of plumose setae.

\section{Discussion}

According to Clark and Ng (2010), the characters that separate the early stages of zoeae of the species of superfamily Trapezioidea are: the spinulation of the antennal protopod, the terminal setation of the antennule, the setation of the maxillule, maxilla, first and second maxillipeds, and medial and dorsolateral processes of the abdominal somites (see Tab. 1). The antennal morphology of $D$. acanthophora follows that observed for the other genera of the superfamily Trapezioidea (Tab. 1). However, the distal spinulation of the antennal protopod in these genera is variable. The antennal protopod and its distal spinulation of D. acanthophora is similar to that of Domecia glabra Alcock, 1899 and Calocarcinus africanus Calman, 1909, which is formed by two rows of similar size spines. Other trapezioids have a distinct spinulation of the antennal protopod: Quadrella maculosa Alcock, 1898 and Quadrella serenei Galil, 1986 show an antennal protopod distally multispinulated (Clark and $\mathrm{Ng}$, 2006); Tetralia cavimana Heller, 1861 and Tetralia rubridactyla Garth, 1971 present two rows of variable size distal spines (Clark and Galil, 1988; Clark and Ng, 2006); Trapezia cymodoce (Herbst, 1799) and Trapezia richtersi Galil \& Lewinsohn, 1983 present two rows of distal spines arranged sparsely (Clark and Galil, 1988; Shikatani and Shokita, 1990; Al-Aidaroos, 1992; Clark and $\mathrm{Ng}, 2006$ ).

The morphology of the larval stages of decapod crustaceans is used in studies to evaluate phylogenetic questions (e.g. Marques et al., 2003; Barros-Alves et al., 2013; Guerao et al., 2014). According to phylogenetic analysis, Clark and $\mathrm{Ng}(2010)$ suggested that the genera Domecia, Quadrella Dana, 1851, Tetralia Dana, 1851 and Trapezia Latreille, 1828 are nested in one clade that is defined by the absence of seta 3.5 and seta 3.4 on the third endopodal segment of the second maxilliped (for details, see Clark and Guerao, 2008), and should be according to a synapomorphy defines the Domecia + Tetralia + Trapezia clade: the presence of one subterminal seta on the distal endopod segment of the maxillule ( $v s$. two subterminal setae). Other synapomorphies define the sister group Domecia + Tetralia, including: the absence of a subterminal seta on the distal endopod lobe of the maxilla; and the absence of dorsolateral process on abdominal somites fourth and fifth (Clark and Ng, 2010). However, D. acanthophora presents two subterminal seta on the distal endopod segment of the maxillule and one subterminal seta on the distal endopod lobe of the maxilla. Thus, these features contradict the synapomorphies mentioned above, since they differ from observed by Clark and $\mathrm{Ng}$ (2010).

As previously discussed by Clark and Guerao (2008) and Clark and $\mathrm{Ng}$ (2010), Calocarcinus Calman, 1909 appears not to be related to the trapezioids. However, a similar morphological characteristic was observed for C. africanus and D. acanthophora: the presence of three pairs of lateral spines on the carapace. Therefore, the presence of this structure seems to be evidence that supports Calocarcinus relationship with the trapezioids (see Tab. 1), but further analysis is needed about this relationship.

Clark and $\mathrm{Ng}$ (2010) suggested, as autapomorphic features of D. glabra, the absence of setae on the proximal endopod segment of the maxillule, four terminal setae and one subterminal seta on the distal endopod segment of the maxillule, the basial setation 
of the first maxilliped arranged as 2, 2, 3, 2, the first endopod segment of the first maxilliped bearing only one seta, and the endopod of the second maxilliped with only four (two subterminal and two terminal) seta in the distal segment. These characters were also observed for the first zoea of D. acanthophora in this study, except the number of subterminal seta on the distal endopod segment of the maxillule (two for $D$. acanthophora vs. one for D. glabra). Thus, we suggest that other characters could be synapomorphies of the genus Domecia.

Some characters of the first zoeal stage that could be used to distinguish D. acanthophora and D. glabra are: the number of aesthetascs in the antennula exopod (three and four, respectively); the number of spines in the lateral carapace (three pairs and two pairs, respectively), wherein the lower pair is not ventrally deflected as in D. glabra; the number of setae in the basial endite of maxilla (4+4 and 5+3, respectively); the pairs of spines on the telson (two and three, respectively); and furcae distally spinulate in D. acanthophora and smooth in D. glabra (see Tab. 1).

The first zoeal stage of $D$. acanthophora exhibits some characters that differ from the other Trapezioidea species, such as the presence of simple setae at the basis of the first maxiliped (vs. plumose setae); the presence of only two pairs of spines on the telson furcae (vs. three pairs); and telson furcae with one pair of plumose setae posteriorly to the well-developed spines (vs. absent) (see Tab. 1). Thus, these characters can be considered as autapomorphy of $D$. acanthophora. Therefore, to prove this hypothesis, it is necessary further zoea I descriptions for the remaining species of the superfamily Trapezioidea.

The current study expands the number of species with first zoeal morphology known in Trapezioidea. Thus, we assert in favor of future studies to increase the number of larval descriptions, and to improve larval culture techniques in the laboratory, enabling the culture of larval stages for the species that the cultivation techniques currently used not guarantee survival and complete larval development, thereby enabling knowledge of a greater number of stages for larval species. This would certainly help to solve taxonomic and phylogenetic problems in the infraorder Brachyura.

\section{ACKNOWLEDGEMENTS}

The authors are indebted to Dr. Maria Lucia NegreirosFransozo, who gave us valuable suggestions for improving the manuscript. DFRA is grateful to $\mathrm{CNPq}$ - Conselho Nacional de Desenvolvimento Científico e Tecnológico (134950/2007-0) for his Master of Science fellowship. JAFP thanks Capes for a $\mathrm{PhD}$ scholarship. RCC is grateful to CNPq (PQ 305919/2014-8). We thank the "Omni Mare" Dive Center for the facilities provided during fieldwork. All sampling was conducted in accordance with applicable Brazilian state and federal laws with respect wild animals.

\section{References}

Ahyong, S.H.; Lowry, J.S.; Alonso, M.; Bamber, R.N.; Boxshall, G.A.; Castro, P.; Gerhen, S.; Karaman, G.S.; Goy, J.W.; Jones, D.S.; Meland, K.; Rogers, C. and Svavarsson, J. 2011. 2011. Subphylum Crustacea Brünnich, 1772. In: Z.Q. Zhang (ed), Animal biodiversity: An outline of higher-level classification and survey of taxonomic richness. Zootaxa, 3148: 165-191.

Al-Aidaroos, A. 1992. The first zoeal stage of four species of Trapezia (Crustacea, Brachyura, Xanthidae). Journal of King Abdulaziz University Marine Science, 3: 57-66.

Alcock, A. 1898. Materials for a carcinological fauna of India. No. 3. The Brachyura Cyclometopa. Part I. The family Xanthidae. Journal of the Asiatic Society of Bengal, 67(2): 67-233.

Alcock, A. 1899. Natural History notes from the Royal Indian Marine Survey Ship 'Investigator,' Commander T. H. Heming, R. N., commanding. Series III. No. 3. On some notable new and rare species of Crustacea. Journal of the Asiatic Society of Bengal, 68(2): 111-119.

Alves, D.F.R.; Cobo, V.J. and Melo, G.A.S. 2006. Extension of the geographical distribution of some brachyuran and porcellanid decapods (Crustacea) to the coast of the State of São Paulo, Brazil. Revista Brasileira de Zoologia, 23(4): 280-283.

Barros-Alves, S.P.; Alves, D.F.R.; Bolla, E.A.; Cobo, V.J. and Negreiros-Fransozo, M.L. 2013. First zoeal stage of Cataleptodius parvulus (Fabricius, 1793) and Xanthodius denticulatus (White, 1848) (Decapoda: Brachyura): larval evidences and systematic position. Zootaxa, 3731(2): 234242.

Borradaile, L.A. 1902. Marine Crustaceans III. The Xanthidae and some other crabs. In: J. Stanley Gardiner (ed) The Fauna and geography of the Maldive and Laccadive Archipelagoes being the account of the work carried on and the collections made by an expedition during the years 1899-1900. Cambridge University Press, Cambridge 1: 237-271.

Calman, W.T. 1909. On a new crab taken from a deep-sea telegraph-cable in the Indian Ocean. Annals and Magazine of Natural History, 3(13): 30-33.

Castro, P.; Ng, P.K.L. and Ahyong, S.T. 2004. Phylogeny and systematics of the Trapeziidae Miers, 1886 (Crustacea: 
Brachyura), with the description of a new family. Zootaxa, 643: 1-70.

Clark, P.F.; Calazans, D.D. and Pohle, G.W. 1998. Accuracy and standardization of brachyuran larval descriptions. Invertebrate Reproduction and Development, 33(2-3): 127-144.

Clark, P.F. and Galil, B.S. 1988. Redescription of Tetralia cavimana Heller, 1861 and Trapezia cymodoce (Herbst, 1799) first stage zoeas with implications for classification within the superfamily Xanthoidea (Crustacea: Brachyura). Proceedings of the Biological Society of Washington, 101(4): 853-860.

Clark, P.F. and Guerao, G. 2008. A description of Calocarcinus africanus Calman, 1909 (Brachyura, Xanthoidea) first zoeal stage morphology with implications for Trapeziidae systematics. Proceedings of the Biological Society of Washington, 121(4): 475-500.

Clark, P.F. and Ng, P.K.L. 2006. First stage zoeas of Quadrella Dana, 1851 [Crustacea: Decapoda: Brachyura: Xanthoidea: Trapeziidae] and their affinities with those of Tetralia Dana, 1851, and Trapezia Latreille, 1828. Hydrobiologia, 560(1): 267-294.

Clark, P.F. and Ng, P.K.L. 2010. Description of the first zoea of Domecia glabra Alcock, 1899 (Crustacea: Brachyura, Domeciidae) and implications for the systematics of the Trapezioidea. Proceedings of the Biological Society of Washington, 123(4): 258-273.

Coelho-Filho, P.A. 2006. Checklist of the Decapods (Crustacea) from the outer continental shelf and seamounts from Northeast of Brazil - REVIZEE Program (NE III). Zootaxa, 1184: 1-27.

Dana, J.D. 1851. On the Classification of the Cancroidea. Scientific Intelligence, III. Zoology. The American Journal of Science and Arts, second series, XII (No.34): 121-131.

Dana, J.D. 1852. Conspectus Crustaceorum, \&c. Conspectus of the Crustacea of the Exploring Expedition under Capt. Wilkes, U.S.N. I. Crustacea Cancroidea. Proceedings of the Academy of Natural Sciences of Philadelphia, 6: 73-86.

De Grave, S.; Pentcheff, N.D.; Ahyong, S.T.; Chan, T.; Crandall, K.A.; Dworschak, P.C.; Felder, D.L.; Feldmann, R.M.; Fransen, C.H.J.M.; Goulding, L.Y.D.; Lemaitre, R.; Low, M.E.Y.; Martin, J.W.; Ng, P.K.L.; Schweitzer, C.E.; Tan, S.H.; Tshudy, D. and Wetzer, R. 2009. A classification of living and fossil genera of decapod crustaceans. Raffles Bulletin of Zoology, Suppl. 21: 1-109.

Desbonne, I. 1867. Brachyoures. In: I. Desbonne and A. Schramm (eds), Crustacés de la Guadeloupe a’après un manuscrit du Docteur Isis Desbonne comparé avec les échantillons de crustacés de sa collection et les dernières publications de MM Henry de Saussure et William Stimpson. Basse Terre, Imprimerie du Gouvemement, ii $+60 \mathrm{p}$.

Eydoux, F. and Souleyet, L.F.A. 1842. Crustacés. In: Voyage autour du monde exécuté pendant les années 1836 et 1837 sur la corvette la Bonite, commandée par M. Vaillant, Capitaine de Vaisseau, Zoologie, Paris 1: 219-272.

Forskål, P. 1775. Descriptiones Animalium Avium, Amphibiorum, Piscium, Insectorum, Vermium; quae in Itinere orientali observavit. Petrus Forskål. Post Mortem Auctoris editit
Carsten Niebuhr. Adjuncta est materia Medica Kahirina. Hauniae, Heineck et Faber, 164p.

Galil, B.S. 1986. Quadrella (Brachyura: Xanthoidea: Trapeziidae) - review and revision. Journal of Crustacean Biology, 6(2): 275-293.

Galil, B.S. and Lewinsohn, C. 1983. Researches on the coast of Somalia. Trapezia richtersi n. sp., a new trapezid crab (Decapoda Brachyura). Monitore Zoologico Italiano, 18(1): 159-166.

Galil, B.S. and Takeda, M. 1986. Resurrection of the genus Jonesius and establishment of a new genus; commensal crabs associated with corals from the Indo-Pacific. Bulletin of the National Science Museum Tokyo ser. A, 12: 163-171.

Garm A. 2004. Revising the definition of the crustacean seta and setal classification systems based on examinations of the mouthpart setae of seven species of decapods. Zoological Journal of the Linnean Society, 142(2): 233-252.

Garth, J.S. 1971 [1969]. Borradaile's Maldivian collections revisited. Journal of the Marine Biological Association of India, 11(1-2): 182-190.

Guerao, G.; Reuschel, S.; Anger, K. and Schubart, C.D. 2014. On the presumed phylogenetic position of Xiphocarididae (Decapoda, Caridea) based on the larval morphology of Xiphocaris elongata. In: D.C.J. Yeo; N. Cumberlidge and S. Klaus (eds), Advances in Freshwater Decapod Systematics and Biology. Crustaceana Monographs, 19: 233-244.

Heller, C. 1861. Beiträge zur Crustaceen-Fauna des rothen Meers. Erster Theil. Sitzungsberichte der mathematisch-naturwissenschaftlichen Classe der Kaiserlichen Akademie der Wissenschaften, Wien, 43: 297-374.

Herbst, J.F.W. 1782-1804. Versuch einer Naturgeschichte der Krabben und Krebse nebst einer Systematischen Beschreibung ihrer Verschiedenen Arten, volumes 1-3. Gottlieb August Lange, Berlin and Stralsund, 515p.

Lai, J,C.Y.; Ahyong, S.T.; Jeng, M.S. and Ng, P.K.L. 2009. Are coral-dwelling crabs monophyletic? A phylogeny of the Trapezioidea (Crustacea: Decapoda: Brachyura). Invertebrate Systematics, 23(4): 402-408.

Latreille, P.A. 1828 [1825]. Art. << Trichodactyle>>.p. 705-706. In: Encyclopédie Méthodique: Entomologie, ou Histoire naturelle des Crutacés, des Arachinides et des Insectes. Volume 10.

Marques, F.P.L.; Pohle, G.W. and Vrbova, L. 2003. On the larval stages of Macrocoeloma diplacanthum (Decapoda: Brachyura: Majidae), and a review of Mithracinae phylogenetic aspects. Journal of Crustacean Biology, 23(1): 187-200.

Melo, G.A.S. 1998. Malacostraca-Eucarida. Brachyura. Oxyrhyncha and Brachyrhyncha. p. 455-515. In: P.S. Young (ed), Catalogue of Crustacea of Brazil. Rio de Janeiro, Museu Nacional (Série Livros No. 6).

Miers, E.J. 1886. Part II. Report on the Brachyura collected by H.M.S. Challenger during the years 1873-76. In: Report on the Scientific Results of the Voyage of H.M.S. Challenger during the years 1873-1876 under the command of Captain George S. Nares, N.R., F.R.S. and the late Captain Frank Tourle Thomson, R.N. prepared under the Superintendence of the late Sir C. Wyville Thomson, Knt., F.R.S. \& C. Regius 
Professor of Natural history in the University of Edinburgh of the civilian scientific staff on board and now of John Murray one of the naturalists of the Expedition. Zoology, Published by Order of Her Majesty's Government. London, Edinburgh and Dublin, HMSO. 17: i-1+1-362, pls. 1-29.

Ng, P.K.L.; Guinot, D. and Davie, P.J.F. 2008. Systema Brachyurorum: Part I. An annotated checklist of extant brachyuran crabs of the world. Raffles Bulletin of Zoology, 17: 1-208.

Ortmann, A. 1893. Abtheilung: Brachyura (Brachyura genuina Boas), II. Unterabthielung: Cancroidea, 2.Section: Cancrinea, 1. Gruppe: Cyclometopa. Die Decapoden-Krebse des Strassburger Museums, mit besonderer Berücksichtigung der von Herrn Dr Döderlein bein Japan und bei den LiuKiuInseln gesammeltern und zur Zeit im Strassburger Museum aufbewahrten Formen. Zoologische Jahrbücher, Abtheilung für Systematik, Geographie und Biologie des Thiere, 7: 411-495.

Sankarankutty, C. 1962. On Decapoda Brachyura from the Andaman and Nicobar Islands. 2. Family Xanthidae. Journal of the Marine Biological Association of India, 4: 121-150.

Shikatani, N. and Shokita, S. 1990. First zoeae of seven trapeziid crabs (Brachyura, Trapeziidae) from the Ryukyu Islands, reared in the laboratory. Galaxea, 9(2): 175-191.

Števčić, Z. 2005. The reclassification of brachyuran crabs (Crustacea: Decapoda: Brachyura). Natura Croatica, 14(Suppl. 1): 1-159. 